\title{
Parasegetibacter luojiensis gen. nov., sp. nov., a member of the phylum Bacteroidetes isolated from a forest soil
}

\author{
Kundi Zhang, Yali Tang, Lei Zhang, Jun Dai, Yang Wang, Xuesong Luo, \\ Ming Liu, Guangchao Luo and Chengxiang Fang
}

Correspondence

Chengxiang Fang

cxfang@whu.edu.cn
College of Life Sciences, Wuhan University, Wuhan 430072, PR China

\begin{abstract}
A novel golden-yellow-coloured strain, designated RHYL-37 ${ }^{\top}$, was isolated from a soil sample from a forest of Euphrates poplar (Populus euphratica) in Xinjiang, China. The cells were strictly aerobic, Gram-staining-negative, heterotrophic, non-spore-forming rods that were motile by gliding. Growth occurred at $17-37{ }^{\circ} \mathrm{C}$ (optimum, $30{ }^{\circ} \mathrm{C}$ ), at $\mathrm{pH} 5.0-9.0$ (optimum, $\mathrm{pH}$ 7.0) and with $0-1 \% \mathrm{NaCl}(\mathrm{w} / \mathrm{v}$; optimum, $0 \%)$. Phylogenetic analysis based on 16S rRNA gene sequences indicated that the novel isolate formed a cluster with members of the genera Segetibacter, Terrimonas, Niastella, Niabella and Chitinophaga in the family 'Chitinophagaceae' in the phylum Bacteroidetes. Sequence similarities with the type strains of recognized species ranged from 90.6 to $94.0 \%$. The predominant isoprenoid quinone was MK-7 and the major cellular fatty acids were iso- $\mathrm{C}_{15: 0}$, iso- $\mathrm{C}_{15: 1}, \mathrm{C}_{16: 0}$ and iso- $\mathrm{C}_{17: 0} 3-\mathrm{OH}$. The DNA G+C content was $39.7 \mathrm{~mol} \%$. On the basis of the phylogenetic, physiological and chemotaxonomic data, strain RHYL-37 ${ }^{\top}$ represents a novel genus and species in the family 'Chitinophagaceae', for which the name Parasegetibacter luojiensis gen. nov., sp. nov. is proposed. The type strain of

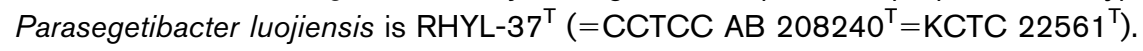

Bacteria constituting the phylum Bacteroidetes (Garrity \& Holt, 2001) are widely distributed over a diverse range of ecological niches. Although they are dominant in marine environments (Bowman et al., 1997), they are also found in soil, fresh water, plants and in the air (Buczolits et al., 2002). During the course of a study on the culturable bacterial community of soil from a forest of Euphrates poplar (Populus euphratica) in Xinjiang, China $\left(40^{\circ} 0^{\prime}-40^{\circ}\right.$ $55^{\prime} \mathrm{N} 84^{\circ} 15^{\prime}-84^{\circ} 30^{\prime} \mathrm{E}$ ), a large number of novel bacterial strains were isolated, most of them belonging to the phyla Proteobacteria and Bacteroidetes. During preliminary identification, one of these isolates, designated RHYL- $37^{\mathrm{T}}$, was found to be a member of the phylum Bacteroidetes and was subjected to further taxonomic investigations. On the basis of the results obtained in this study, we propose that strain RHYL- $37^{\mathrm{T}}$ represents a new genus and species in the phylum Bacteroidetes.

Strain RHYL- $37^{\mathrm{T}}$ was isolated from a soil sample that was diluted with sterile water; the dilutions were plated onto $0.5 \times$ R2A agar (Difco). After 1 week of incubation at

The GenBank/EMBL/DDBJ accession number for the $16 \mathrm{~S}$ rRNA gene sequence of strain RHYL-37 ${ }^{\top}$ is EU877263.

Detailed fatty acid compositions of strain RHYL-37 $7^{\top}$ and its closest phylogenetic neighbours are available as supplementary material with the online version of this paper.
$30{ }^{\circ} \mathrm{C}$, single colonies were transferred onto new plates of $0.5 \times \mathrm{R} 2 \mathrm{~A}$ agar and on $0.3 \times$ marine agar $(\mathrm{MA})[11.22 \mathrm{~g}$ marine broth 2216 (MB; Difco) and $15 \mathrm{~g}$ agar per litre distilled water]. Routine cultivation was performed on $0.3 \times \mathrm{MA}$ or in $0.3 \times \mathrm{MB}$ at $30{ }^{\circ} \mathrm{C}$ for $24 \mathrm{~h}$ to 1 week.

Cell morphology was examined by phase-contrast (Olympus BX51) and transmission electron (Hitachi $8100)$ microscopy, using cells negatively stained with $1 \%$ (w/v) phosphotungstic acid after air drying. Gram staining was carried out according to the classical procedure described by Doetsch (1981). Gliding motility was assessed as described by Bowman (2000). Catalase and oxidase activities were revealed by bubble production in $3 \%(\mathrm{v} / \mathrm{v})$ $\mathrm{H}_{2} \mathrm{O}_{2}$ and using $1 \%(\mathrm{w} / \mathrm{v})$ tetramethyl-p-phenylenediamine, respectively. Growth under anaerobic conditions was tested in a GasPak (BBL) jar at $30{ }^{\circ} \mathrm{C}$ for 10 days on $0.3 \times$ MA. Carbon-source utilization and enzyme activities were tested by using the API 20NE, API 20E, API ID 32GN and API ZYM test kits (bioMérieux) at $30{ }^{\circ} \mathrm{C}$ for 10 days. Hydrolysis of cellulose, casein, chitin, DNA, tyrosine and starch was tested according to the methods of Smibert \& Krieg (1994). The presence of flexirubin pigments was assessed from a colour shift after exposure to a $20 \%(\mathrm{w} / \mathrm{v})$ $\mathrm{KOH}$ solution (Reichenbach, 1992). Growth at 4, 10, 17, $22,30,37,42$ and $50{ }^{\circ} \mathrm{C}$ and at $\mathrm{pH} 5.0-10.0$ (at $1.0 \mathrm{pH}$ unit intervals) was assessed after 5 days of incubation in $0.3 \times$ 
$\mathrm{MB}$; for $\mathrm{pH}$ experiments, the $\mathrm{pH}$ was adjusted using $1 \mathrm{M}$ $\mathrm{HCl}$ or $\mathrm{NaOH}$ and the medium was then filter-sterilized $(0.2 \mu \mathrm{m}$ pore size). Salt tolerance was tested on $0.5 \times \mathrm{R} 2 \mathrm{~A}$ agar supplemented with $1-10 \%(\mathrm{w} / \mathrm{v}) \mathrm{NaCl}$ (at $1 \%$ intervals) after 5 days of incubation. Growth was also evaluated on nutrient agar (NA; Difco), tryptic soy agar (TSA; Difco), $0.1 \times$ TSA and MacConkey agar (Difco) at $30{ }^{\circ} \mathrm{C}$

Cells of strain RHYL- $37^{\mathrm{T}}$ were strictly aerobic, Gramstaining-negative, heterotrophic, non-spore-forming rods that were motile by gliding. Other characteristics are summarized in the species description, and those that differentiate strain RHYL- $37^{\mathrm{T}}$ from closely related type strains are shown in Table 1.

The genomic DNA was extracted with a Bacteria Genomic DNA Isolation kit (Shanghai Chaoshi Bio Technologies Co. Ltd). The 16S rRNA gene was amplified by PCR using bacterial universal primers (Rainey et al., 1996), and the PCR products were sequenced by Invitrogen Biotechnology Co. Ltd. An almost-complete $16 \mathrm{~S}$ rRNA gene sequence (1442 bp) of strain RHYL- $37^{\mathrm{T}}$ was determined and subjected to comparative analysis. Sequence similarity

Table 1. Differentiating characteristics of strain $\mathrm{RHYL}-37^{\top}$ and related taxa

Strains: 1, RHYL- $37^{\mathrm{T}}$ (data from this study); 2, Segetibacter koreensis KCTC $12655^{\mathrm{T}}$; 3, Niastella koreensis KACC $11465^{\mathrm{T}}$; 4 , Niastella yeongjuensis

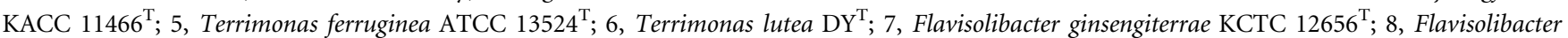
ginsengisoli KCTC $12657^{\mathrm{T}} ; 9$, Chitinophaga pinensis DSM $2588^{\mathrm{T}} ; 10$, Niabella aurantiaca KACC $11698^{\mathrm{T}}$. Data for reference strains are from An et al. (2007), Weon et al. (2006), Yoon \& Im (2007), Xie \& Yokota (2006), Sangkhobol \& Skerman (1981) and Kim et al. (2007) unless indicated. All strains are negative for assimilation of inositol and nitrate reduction. All strains have MK-7 as the major respiratory quinone. +, Positive; - , negative; w, weak reaction; ND, no data available.

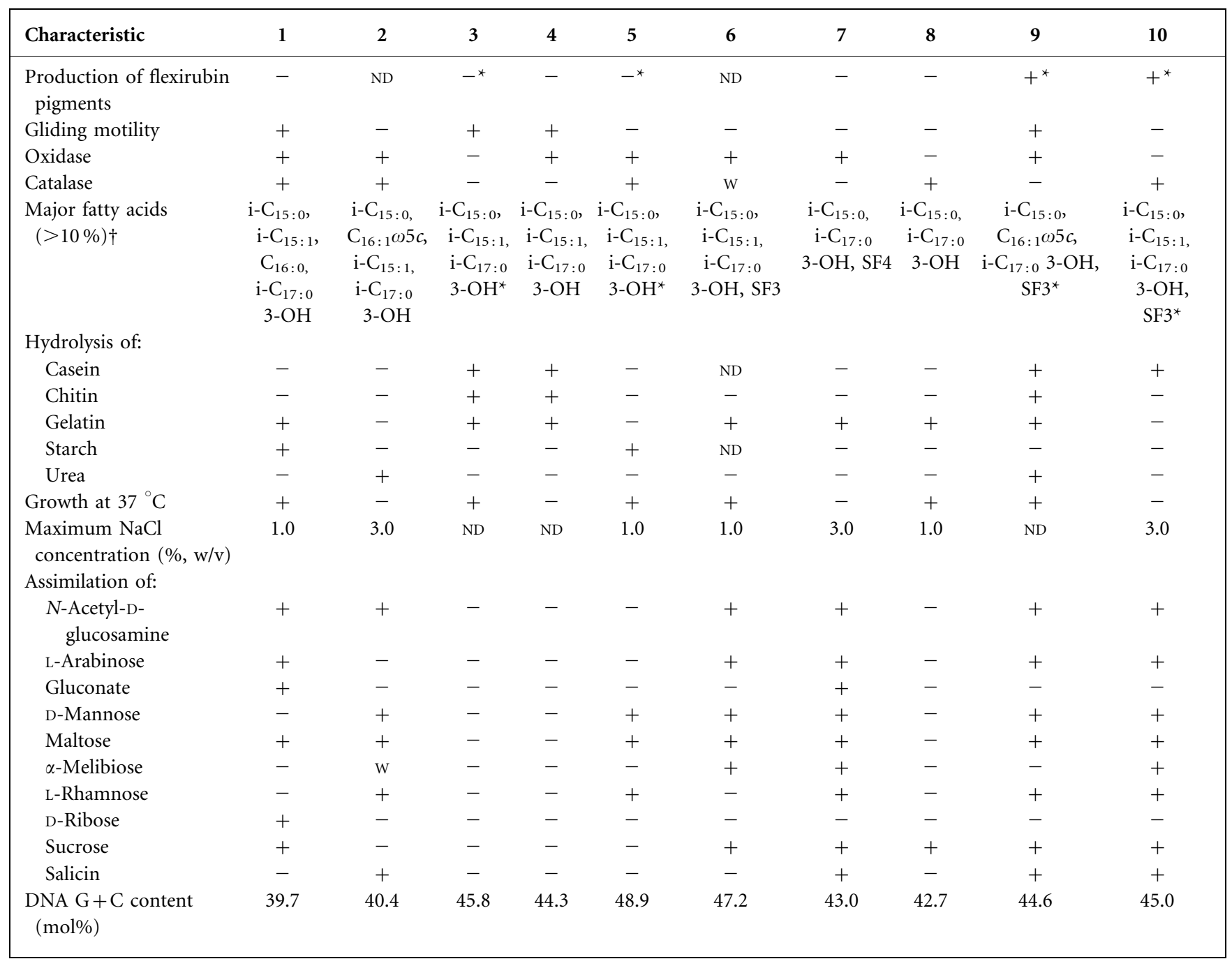

${ }^{\star}$ Data from this study.

$\dagger \mathrm{i}$, Iso-branched; SF3, summed feature 3 (iso- $\mathrm{C}_{15: 0}$ 2-OH and/or $\mathrm{C}_{16: 1} \omega 7 c$ ); SF4, summed feature 4 (iso- $\mathrm{C}_{17: 1} \mathrm{I}$ and/or anteiso- $\mathrm{C}_{17: 1} \mathrm{~B}$ ). 
was searched by NCBI BLAST and calculated by pairwise alignment obtained from the EzTaxon database (Chun et al., 2007). Analysis of the 16S rRNA gene sequence was performed by using the software package MEGA version 4.0 (Tamura et al., 2007), after multiple alignment of the data by CLUSTAL_X (Thompson et al., 1997). Phylogenetic trees were inferred using the neighbour-joining (Saitou \& Nei, 1987) and maximum-parsimony (Fitch, 1971) methods. Bootstrap analysis based on 1000 replications was undertaken to test the robustness of the phylogenetic trees (Felsenstein, 1985). All branches of the neighbour-joining tree (Fig. 1) were also present in the maximum-parsimony tree (not shown).

Phylogenetic analysis based on 16S rRNA gene sequences indicated that the isolate formed a cluster with members of the genera Segetibacter, Terrimonas, Niastella, Flavisolibacter, Niabella and Chitinophaga (Fig. 1). The family 'Chitinophagaceae' has recently been proposed to group these genera (http://www.bacterio.net). However, the levels of $16 \mathrm{~S}$ rRNA gene sequence similarity with the type strains of recognized species of these genera ranged from 90.6 (Chitinophaga species) to $94.0 \%$ (Terrimonas species), demonstrating that strain RHYL- $37^{\mathrm{T}}$ is a distinct member of the family 'Chitinophagaceae', phylum Bacteroidetes.

Biomass for molecular systematic and chemotaxonomic studies was obtained after incubation at $30{ }^{\circ} \mathrm{C}$ for 3 days in shaken flasks containing R2A. Isoprenoid quinones were isolated from lyophilized cells as described by Collins et al. (1977), and were analysed by HPLC (UltiMate 3000; Dionex) as described by Xie \& Yokota (2003). Genomic DNA of strain RHYL- $37^{\mathrm{T}}$ was prepared according to a modification of the procedure of Wilson (1987). The DNA $\mathrm{G}+\mathrm{C}$ content was determined by HPLC according to Mesbah et al. (1989), using reversed-phase HPLC. To determine its whole-cell fatty acid profile, strain RHYL- $37^{\mathrm{T}}$ was cultured at $30{ }^{\circ} \mathrm{C}$ for 4 days on R2A agar. The type strains of some of the closest phylogenetic neighbours of strain RHYL- $37^{\mathrm{T}}$ (Niastella koreensis KACC $11465^{\mathrm{T}}$, Terrimonas ferruginea ATCC $13524^{\mathrm{T}}$, Chitinophaga pinensis DSM $2588^{\mathrm{T}}$ and Niabella aurantiaca KACC $11698^{\mathrm{T}}$ ) were cultured under the same conditions and analysed in parallel. Analysis of fatty acid methyl esters was carried out according to the standard protocol of the Sherlock Microbial Identification System (MIDI).
The major respiratory quinone of strain $\mathrm{RHYL}-37^{\mathrm{T}}$ was MK-7. The $\mathrm{G}+\mathrm{C}$ content of the genomic DNA was $39.7 \mathrm{~mol} \%$, a value much lower than those of the most closely related organisms $(47.2-48.9 \mathrm{~mol} \%$ for members of the genus Terrimonas and 44.3-45.8 mol\% for members of the genus Niastella). As shown in Table 1, the major fatty acids of strain RHYL- $37^{\mathrm{T}}$ were iso- $\mathrm{C}_{15: 0} \quad(19.5 \%)$, iso- $\mathrm{C}_{15: 1}(14.7 \%), \mathrm{C}_{16: 0}(10.1 \%)$ and iso- $\mathrm{C}_{17: 0} 3-\mathrm{OH}$ $(16.3 \%)$. The complete fatty acid compositions of strain RHYL- $37^{\mathrm{T}}$ and its phylogenetic neighbours are given in Supplementary Table S1 (available in IJSEM Online). The presence of $5.2 \%$ iso- $\mathrm{C}_{13: 0} 3-\mathrm{OH}$ and $3.7 \%$ anteiso- $\mathrm{C}_{15: 1}$, the absence of $\mathrm{C}_{16: 1} \omega 5 c$ and differences in the proportions of other fatty acids distinguished strain RHYL- $37^{\mathrm{T}}$ from related organisms.

In terms of physiological and biochemical properties, strain RHYL $-37^{\mathrm{T}}$ differed from most members of related genera in being able to glide and to hydrolyse starch. Furthermore, it could be distinguished from Segetibacter koreensis KCTC $12655^{\mathrm{T}}$ on the basis of growth at $37^{\circ} \mathrm{C}$, the ability to hydrolyse gelatin and absence of urease. In addition, strain RHYL $-37^{\mathrm{T}}$ could assimilate several carbohydrates, whereas the two Niastella species could not assimilate any of the substrates included in the API 20NE and API ID 32 GN test kits. The characteristics that differentiate strain RHYL- $37^{\mathrm{T}}$ from closely related species are listed in Table 1.

On the basis of a variety of taxonomic criteria, strain RHYL- $37^{\mathrm{T}}$ formed a distinct and coherent taxonomic entity. Thus, it represents a novel genus and species in the phylum Bacteroidetes, for which the name Parasegetibacter luojiensis gen. nov., sp. nov. is proposed.

\section{Description of Parasegetibacter gen. nov.}

Parasegetibacter (Pa.ra.se.ge.ti.bac'ter. Gr. prep. para beside; N.L. masc. n. Segetibacter the name of a bacterial genus; N.L. masc. n. Parasegetibacter resembling the genus Segetibacter).

Cells are Gram-staining-negative, aerobic, non-sporeforming rods devoid of flagella but motile by gliding. Oxidase- and catalase-positive. Flexirubin pigments are not produced. Nitrate is not reduced to nitrite. The major respiratory quinone is MK-7. The DNA G $+\mathrm{C}$ content of the type strain of the type species is $39.7 \mathrm{~mol} \%$.

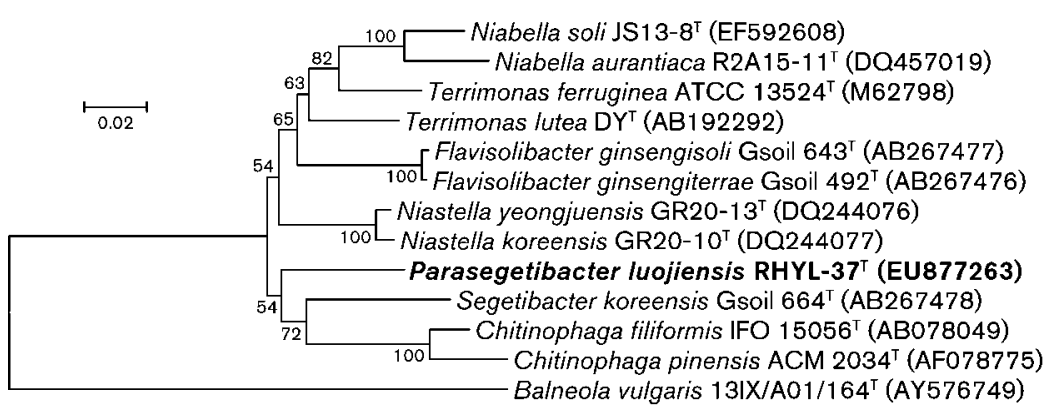

Fig. 1. Neighbour-joining tree, showing the phylogenetic positions of strain RHYL-37 ${ }^{\top}$ and related taxa based on 16S rRNA gene sequences. Bootstrap values $(>50 \%)$ are shown at nodes as percentages of 1000 replicates. The sequence of Balneola vulgaris $13 \mathrm{IX} / \mathrm{A} 01 / 164^{\top}$ was used as an outgroup. Bar, 0.02 substitutions per nucleotide position. 
Phylogenetically, the genus Parasegetibacter is a member of the family 'Chitinophagaceae', phylum Bacteroidetes. The type species is Parasegetibacter luojiensis.

\section{Description of Parasegetibacter luojiensis sp. nov.}

Parasegetibacter luojiensis (lu.o.ji.en'sis. N.L. masc. adj. luojiensis pertaining to Luojia hill, where the campus of Wuhan University is located, where studies of the type strain were conducted).

The characteristics are the same as those given in the genus description. In addition, cells are $0.3-0.8 \mu \mathrm{m}$ in diameter and $2-20 \mu \mathrm{m}$ long. Colonies on $0.3 \times \mathrm{MA}$ are golden yellow, smooth, convex and circular with regular edges, 2 $3 \mathrm{~mm}$ in diameter after 4 days of incubation. Growth occurs at $17-37{ }^{\circ} \mathrm{C}$, at $\mathrm{pH} 5.0-9.0$ and in the presence of 0 $1 \% \mathrm{NaCl}(\mathrm{w} / \mathrm{v})$; growth is optimal at $30{ }^{\circ} \mathrm{C}, \mathrm{pH} 7.0$ and in the absence of $\mathrm{NaCl}$. Hydrolyses starch and tyrosine. Does not hydrolyse casein, chitin, cellulose or DNA. In API 20NE and API ID 32 GN strips, assimilates D-glucose, Larabinose, D-mannose, $\mathrm{N}$-acetyl-D-glucosamine, maltose, sucrose, D-ribose, potassium 2-ketogluconate and potassium 5-ketogluconate. Does not assimilate L-rhamnose, potassium glucosamine, capric acid, adipic acid, malic acid, trisodium citrate, phenylacetic acid, inositol, itaconic acid, suberic acid, sodium malonate, sodium acetate, lactic acid, L-alanine, glycogen, 3-hydroxybenzoic acid, L-serine, Dmannitol, salicin, melibiose, L-fucose, D-sorbitol, propionic acid, capric acid, valeric acid, trisodium citrate, 3hydroxybutyric acid, 4-hydroxybenzoic acid or L-proline. In API 20NE and API ZYM strips, tests positive for aesculin and gelatin hydrolysis and alkaline phosphatase, esterase (C4), valine arylamidase, cystine arylamidase, trypsin, $\alpha$-chymotrypsin, acid phosphatase, naphthol-ASBI-phosphohydrolase, $\alpha$-galactosidase, $\beta$-galactosidase, $\beta$ glucosidase, $N$-acetyl- $\beta$-glucosaminidase, $\alpha$-mannosidase and $\alpha$-fucosidase activities; weakly positive for esterase lipase (C8) and lipase (C14) activities; negative for nitrate reduction, indole production, glucose fermentation and arginine dihydrolase, urease, $\beta$-glucuronidase and $\alpha$ glucosidase activities. The major cellular fatty acids are iso- $\mathrm{C}_{15: 0}$, iso- $\mathrm{C}_{15: 1}, \mathrm{C}_{16: 0}$ and iso- $\mathrm{C}_{17: 0} 3-\mathrm{OH}$.

The type strain, RHYL- $37^{\mathrm{T}}$ (=CCTCC AB $208240^{\mathrm{T}}$ $=$ KCTC $22561^{\mathrm{T}}$ ), was isolated from soil from a forest of Euphrates poplar in Xinjiang, China.

\section{Acknowledgements}

This work was funded by the R \& D Infrastructure and Facility Development Program from the Ministry of Science and Technology of the People's Republic of China (grant no. 2005DKA21208).

\section{References}

An, D. S., Lee, H. G., Im, W. T., Liu, O. M. \& Lee, S. T. (2007). Segetibacter koreensis gen. nov., sp. nov., a novel member of the phylum Bacteroidetes, isolated from the soil of a ginseng field in South Korea. Int J Syst Evol Microbiol 57, 1828-1833.

Bowman, J. P. (2000). Description of Cellulophaga algicola sp. nov., isolated from the surfaces of Antarctic algae, and reclassification of Cytophaga uliginosa (ZoBell and Upham 1944) Reichenbach 1989 as Cellulophaga uliginosa comb. nov. Int J Syst Evol Microbiol 50, 18611868.

Bowman, J. P., McCammon, S. A., Brown, M. V., Nichols, D. S. \& McMeekin, T. A. (1997). Diversity and association of psychrophilic bacteria in Antarctic sea ice. Appl Environ Microbiol 63, 3068-3078.

Buczolits, S., Denner, E. B. M., Vybiral, D., Wieser, M., Kämpfer, P. \& Busse, H.-J. (2002). Classification of three airborne bacteria and proposal of Hymenobacter aerophilus sp. nov. Int J Syst Evol Microbiol 52, 445-456.

Chun, J., Lee, J.-H., Jung, Y., Kim, M., Kim, S., Kim, B. K. \& Lim, Y. W. (2007). EzTaxon: a web-based tool for the identification of prokaryotes based on $16 \mathrm{~S}$ ribosomal RNA gene sequences. Int J Syst Evol Microbiol 57, 2259-2261.

Collins, M. D., Pirouz, T., Goodfellow, M. \& Minnikin, D. E. (1977). Distribution of menaquinones in actinomycetes and corynebacteria. $J$ Gen Microbiol 100, 221-230.

Doetsch, R. N. (1981). Determinative methods of light microscopy. In Manual of Methods for General Bacteriology, pp. 21-33. Edited by P. Gerhardt, R. G. E. Murray, R. N. Costilow, E. W. Nester, W. A. Wood, N. R. Krieg \& G. H. Phillips. Washington, DC: American Society for Microbiology.

Felsenstein, J. (1985). Confidence limits on phylogenies: an approach using the bootstrap. Evolution 39, 783-791.

Fitch, W. M. (1971). Toward defining the course of evolution: minimum change for a specific tree topology. Syst Zool 20, 406-416.

Garrity, G. M. \& Holt, J. G. (2001). The road map to the Manual. In Bergey's Manual of Systematic Bacteriology, 2nd edn, vol. 1, pp. 119166. Edited by D. R. Boone, R. W. Castenholz \& G. M. Garrity. New York: Springer.

Kim, B. Y., Weon, H. Y., Yoo, S. H., Hong, S. B., Kwon, S. W., Stackebrandt, E. \& Go, S. J. (2007). Niabella aurantiaca gen. nov., sp. nov., isolated from a greenhouse soil in Korea. Int $J$ Syst Evol Microbiol 57, 538-541.

Mesbah, M., Premachandran, U. \& Whitman, W. B. (1989). Precise measurement of the $\mathrm{G}+\mathrm{C}$ content of deoxyribonucleic acid by highperformance liquid chromatography. Int J Syst Bacteriol 39, 159-167.

Rainey, F. A., Ward-Rainey, N., Kroppenstedt, R. M. \& Stackebrandt, E. (1996). The genus Nocardiopsis represents a phylogenetically coherent taxon and a distinct actinomycete lineage: proposal of Nocardiopsiaceae fam. nov. Int J Syst Bacteriol 46, 1088-1092.

Reichenbach, H. (1992). The order Cytophagales. In The Prokaryotes, 2nd edn, vol. 4, pp. 3631-3675. Edited by A. Balows, H. G. Trüper, M. Dworkin, W. Harder \& K. H. Schleifer. New York: Springer.

Saitou, N. \& Nei, M. (1987). The neighbor-joining method: a new method for reconstructing phylogenetic trees. Mol Biol Evol 4, 406-425.

Sangkhobol, V. \& Skerman, V. B. D. (1981). Chitinophaga, a new genus of chitinolytic myxobacteria. Int J Syst Bacteriol 31, 285-293.

Smibert, R. M. \& Krieg, N. R. (1994). Phenotypic characterization. In Methods for General and Molecular Bacteriology, pp. 607-654. Edited by P. Gerhardt, R. G. E. Murray, W. A. Wood \& N. R. Krieg. Washington, DC: American Society for Microbiology.

Tamura, K., Dudley, J., Nei, M. \& Kumar, S. (2007). MEGA 4: molecular evolutionary genetics analysis (MEGA) software version 4.0. Mol Biol Evol 24, 1596-1599.

Thompson, J. D., Gibson, T. J., Plewniak, F., Jeanmougin, F. \& Higgins, D. G. (1997). The CLUSTAL_X windows interface: flexible 
strategies for multiple sequence alignment aided by quality analysis tools. Nucleic Acids Res 25, 4876-4882.

Weon, H. Y., Kim, B. Y., Yoo, S. H., Lee, S. Y., Kwon, S. W., Go, S. J. \& Stackebrandt, E. (2006). Niastella koreensis gen. nov., sp. nov. and Niastella yeongjuensis sp. nov., novel members of the phylum Bacteroidetes, isolated from soil cultivated with Korean ginseng. Int J Syst Evol Microbiol 56, 1777-1782.

Wilson, K. (1987). Preparation of genomic DNA from bacteria. In Current Protocols in Molecular Biology, pp. 2.4.1-2.4.5. Edited by F. M. Ausubel, R. Brent, R. E. Kingston, D. D. Moore, J. G. Seidman, J. A. Smith \& K. Struhl. New York: Green Publishing \& Wiley-Interscience.
Xie, C. H. \& Yokota, A. (2003). Phylogenetic analysis of Lampropedia hyalina based on the 16S rRNA gene sequence. J Gen Appl Microbiol 49, 345-349.

Xie, C. H. \& Yokota, A. (2006). Reclassification of [Flavobacterium] ferrugineum as Terrimonas ferruginea gen. nov., comb. nov., and description of Terrimonas lutea sp. nov., isolated from soil. Int J Syst Evol Microbiol 56, 1117-1121.

Yoon, M. H. \& Im, W. T. (2007). Flavisolibacter ginsengiterrae gen. nov., sp. nov. and Flavisolibacter ginsengisoli sp. nov., isolated from ginseng cultivating soil. Int J Syst Evol Microbiol 57, 18341839. 